\title{
Strategic Entrepreneurship: Issues and Challenges
}

\author{
Branislav Djordjevic \\ 18000 N IS \\ Str. Bulevar Nemanjica 78/49 \\ Republic of Srbija
}

\section{Doi:10.5901/mjss.2013.v4n7p155}

\section{Abstract}

There is a wide variety of types of entrepreneurs, but no one formula for success. However, there are many successful entrepreneurs. Understanding why some entrepreneurs succeed while others fail is important to help future entrepreneurs in their efforts to be ssuccessful. Entrepreneurship is the economic engine driving many nations" economies in the global competitive landscape. Entrepreneurship and innovation have become important for young and old and for large and small firms in all types of industries. Research conducted has shown that in receant years almost 100 percent of the new jobs in the United States were created by entrepreneurial firms of less than two years age". As result, this chapter focuses on strategic entrepreneurship.

Keywords: Consumer, organization, research, implication, environment influence, etc.

\section{The definition of strategic entrepreneurship}

Strategic entrepreneurship is taking entrepreneurial action using a strategic perspective. More specifically, it involves engaing in simultaneous opportunity seeking and competitive advantage seeking behaviors to design implement entrepreneurial strategies to create wealth. These actions can be taken by individuals or by corporations. Such activity in particularly important in the evolving 21-st century landscspe.

The competitive lanscape that has evolved in the 21-st century presents firms with sustantial change, a global marketplace, and significant complexity and uncertainty. Because of this uncertain envornment, firms cannot easily predict the future. As a result, they must develop strategic flexibility to have a range of strategic alternatives that they can implement as needed. To do so, they must acquire resources and build the capabiliti- es that allow them to take necessary actions to adapt to a dynamic environment or to proact in that environment. In this environment, entrepreneurs and entrepreneurial managers design and implement actions that capture more of existing markets from less aggressive and innovative competitors while creating new markets. In effect, they are trying to create tomorrow's business.

Creating tomorrows's business requires identifying opportunities, and developing innovation. In other words, firms must be entreprenurial and innovative. Innovations are critical to companies' efforts to differentiate their goods or services from competitors in ways that create additional or new value for customers. Thus, entrepreneurial competencies are important for firms to achieve and sustain competitive advantage for a period of time.

To describe how firms produce and manage innovation, we examine several topics in this chapter. To set the stage, we first examine entrepreneurship and innovation in a strategic contex. Next, we discusss international entrepreneurship, a phenomenon reflecting the increase use of entrepreneurship in countries throughout the world. Internally, firms innovate through either autonomous or induced strategic behavior. After our desciption of these internal corporate venturing activities, we discuss astions taken by firms to implement the innovations resulting from those two tepes of strategic behavior. In addition to innovating through internal activities, firms can gain access to other companies' innovations or innovative capabilities 
through strategic alliances and acquisitions. Following our discussion of these topics is a description of entrepreneurship in start-up ventures and smaller firms. This section closes both the chapter and our analysis of acti- ons that firms take to successfully implement strategies.

\section{The differences between Strategic entreprenurship and Innovation}

Joseph Schumpeter viewed entrepreneurship as a process of "creative description" through which existing products or methods of production are destroyed and replaced with new ones. Thus, entreprenurship is "concerned with the discovery and exploitation of profitable opportunities." Entrepreneurial activity is an important mechanism for creating changes, as well as for helping firms adapt to changes created by others. Firms that encourage entreprenurship are risk takers, are commited to innovation, and act proactively in that they try to create opportunities rather than waiting to respond to opportunities created by others.

Entrepreneurial opportunities represent conditions in which new products or services can satisfy a need in the market. The essence of entrepreneurship is to identify and exploit these opportunities. Importantly, enterpreneurs or entrepreneurial managers must be able to identify opportunities not perceived by others. Identifying these opportunities in a dynamic and uncertain environment requires an enterpreneurial mind-set that entails the passionate pursuitt of opportunities.

After identifying the opportunities, enterpreneurs take action to exploit them and establish a competitive advantage. The process of identifying and pursuing opportunities is entrepreneurial, but this activity alone is rarely enough to create maximum wealth or even to survive over time. Actions must be valuable, rare, diffucult to imitate and nonsubstitutable to create and sustain a competitive advantage. Without the competitive advantage, success will be only temporary. An innovation may be valuable and rare early in its life, if a market perspective is used in its development. Hawoever, strategic action must be taken to introduce the new product to the market and protect its position in the market against competitors (difficult to imaitate) to gain a competitive advantage. These actions combined represent strategic entrepreneurship.

Peter Drucker argues that "innovation is the specific function of entrepreneurship, whether in an existing business, a public service institution, or a new venture started by a lone individual". Moreover, Drucker suggests that innovation is "the means by which the entrpreneur either creates new wealth producing resources or endows existing resources with enhanced potential for creating wealth". Thus, enterpreneurship and the innovation resulting from it are important for large and small firms, as well as for startup ventures, as they compete in the $21^{\text {st }}$ century competitive landscape. Therefore, we can conclude that, "Entrepreneurship and innovation are central to the creative process in the economy and to promoting growth, increasing productivity and creating jobs."

Innovation is a key ourcome firms seek through entrepreneurship and is often the source of competitive success. In Rosabeth Moss Kanter's words "Winning in business today demands innovation. Companies that innovate reap all the advantage of a first mover."

For example, research results show that firms competing in global industries that invest more in innovation also achieve the highest returns. In fact, investors often react positively to the introduction of a new product, thereby increasing the price of a firm's stock. Innovation is an essential feature of highperformance firms. Furthemore, "innovation may be required to maintain or achieve competitive parity, much less a competitive advantage in many global markets.

In his classic work, Schumpeter argued that firms engage in three types of innovative activity.

Invention is the act of creating or developing a new product or proc- ess. Innovation is the process of creating a commercial product from an invention. Thus, an innvention brings something new into being, while an innovation brings something new into use. Accordingly, tehnical criteria are used to determine the success of an invention, whereas commercial criteria are used to determine the successs of invention, whereas commercial criteria are used to determine the success of an innovation. Finally, imitation is the 
adoption of an innovation by simple firms. Imitation usaually leads to product or process standardization, and product based on imitation often are offered at lower prices, but without as many features.

In the Unitaed States in particular, innovation is the most critical of the three types of innovative activity that occur in firms. Many companies are able to create ideas that lead to inventions, but commercializing those inventions through innovations has, at times, proved difficult. Appproximately 80 percent of R\&D occurs in large firms, but these same firms produce fewer than 50 percent of the patents.

Innovations produced in large established firms are often referred to as corporate entrepreneurship.

Corporate entrepreneurship is a proces whereby an individual or group in an exicting organization creates a new venture or develops an innovation. Overall, corporate entreprenurship is the sum of a firm's innovation, renewal and venturing efforts. Evidence suggests that corporate entrepreneurship practices are facilitated through the effective use of a firm's strategic management process and effectively using the firm's human capital. Determining how to harmess the ingenuity of a firm's employees and how to reward them for while retaining some of the rewards of the entrepreneurial efforts for the shareholders' benefit facilitates the energency of value-creating corporate entrepreneurship.

Many people tend not to distinquish between effectivenes and efficency. Yet effectiveness stressess the need for actions to attain goals, whereas efficency relates input and output. If a company generates a large volume of sale, it may be effective in using its capital investment that gives an indication of efficency. It is important, however, for new ventures to generate sales first, for without sales there is no chance of earning any profit. Without effective operation to keep the venture alive, it will die before it can reach the promised land of profit.

For the reason, the focal point of an entrepreneurial strategy for a new venture often favours effectiveness rather than efficency. To turn out the first product and to land the first sale are far more important to new venture fiunders than worrying about efficie- ncy or profit.

For this reason, too, it is important for owner/managers not to get hung up on organization and structure. Too many corporate-style thinkers try to learn on organization for the firm's survival; their strategy then becomes survival, not innovation. Entrepreneurial thinkers concentrate on getting things done.

\section{Entrepreneurs and Entrepreneurial Capabilities}

Entrepreneurs are individuals, acting independently or as part of an organization, who create a new venture or develop an innovation and take risks entering them into the marketplace. Entrepreneurs can be independent individuals or surface in an organizat- ion at any level. Thus, top-level managers, middle and first-level managers, staff personnel, and those producing the company's good or service can all be entrepreneurs.

Firms need employees who think entrepreneurially. Top-level managers should try to establish an entrepreneurial culture that inspires individuals and groups to engage in corporate entrepreneurship. Apple Computer's Steve Jobs is committed to this effort, beleiving one of his key responsibilities is to help Apple become more entrepreneurial. And, Apple has introduced some innovately designed products., such as its recent iMac with its 15-inch liquid crystal display attached to the base computer with a chrome swiv- el bar. Some believe that it looks more like a desk lamp. Apple is using the new design to capture a larger share of the PC market.

Of course, to create and commercialize products such as the iMac requires not only intellectual capital, but an entrepreneurial mind-set as wll. It also requires entrepreneurial competence. Returning to the Opening Case, entrepreneurial competence involves effective knowledge of the business and technology, a passion for the business, and a risk orientation. In most cases, knowledge must be trenasferred to other in the organization, even in smaller ventures, to enhance the entrepreneurial competence of the firm. The transfer is likely to be more difficult in large firms. Research has shown, however, that units within firms are more innovative if they have access to new knowledge. 
Transfering knowledge can be difficult, because the receiving party must have adequate absorptive capacity to learn the knowledge. This requires that the new knowledge be linked to the existing knowledge. Thus, managers will need to develop the capabilities of their human capital to build on their current knowledge base while incrementally expanding that knowledge.

Developing innovations and achieving success in the marketplace requires effecti- ve human capital. In particular, firms must have strong human capital in their R\&D organization. However, a firm must have strong human capital throughout its workforce if employees are to be innovative. For example, Winspec West Manufacturing Inc. credits its positive market position to innovation produced by its strong employee base. In fact, the managers are very careful in hiring. Even in jobs with seemingly low challenges, they try to hire high potential employees. For one sekretarial position, the managers hired a person with an MBA in finance, that person went on to serve as the acting chief finacial officer.

Having the intellectual talent is only part of the challenge. The management of the talent to realize its potential is critical for a firm to be entrepreneurial. Managers must develop the culture and infuse it with the values espoused by successful entrepreneurs. Additionaly, managers should empower employees at all levels to act independetly.

People tend to perceive professionals as problem-solvers. If there is no problem, there is little need for professionals. For example, a happily married couple has not need to see a marriage consellor, a healthy person does not consult a psychiatrist. A bussiness running well and making a profit will not seek an outside consultant. If the foregoing sounds like an attack on professionals or professionalism, it isn't meant to be. Without a historical drive to develop professional standards, the world would still be relying on barbers to perform surgery and fortune tellers to predict the world economy. Proffesionalism which means knowledge of and adherence to be abolished standards of performance in a given field is necessary for anyone who wonts to do more than middle through. This harmful only when it is allowed to stille initiative.

\section{International Entrepreneurship}

Entrepreneurship is a global phenomenon. It is the top of public policy agendas in many of the world's countries, including Finland, Germany, Israel, Ireland and France, among others. In Nortrhernd Irelamd, for example, the ministar for enterprise trade, and investment told business people that their current and future commercial success would be affected by the degree to which they decided to emphasize R\&D and innovation (critical components of entrepreneurship.

According to some researches who are studying economies throughout the world, virtually all industrial nations "are experiencing some form of tranasformation in their economies, from the dramatic move from centrally planned to market economies in East - central Europe to the efforts by Asian countries to return to their recent high growth levels.

While entrepreneurship is a global phenomenon, there are differences in the rate of entrepreneurship across countries. A recent study of 29 countries found that the percentage of adults involved in entrepreneurial activity ranged from a high of more than 20 percent in Mexico to a low of approximately 5 percent in Belgium. The United States had a rate of about 13 percent. Importantly, this study also found a strong positive relationship between the rate of entrepreneurial activity and economic development in the country.

Culture is one of the reasons for the differences in rates of entrepreneurship among different countries. For example, the tension between individualism and colectivism is important for entrepreneurship; research shows that entrepreneurship declines as colletivism is emphasized. Simultaneously, however, research results suggest that exceptionally high levels of individaul might be dysfuncional for entrepreneurship. Viewed collectively, these results appear to call for a balance between individual initiative and a spirit of cooperation and group ownership of innovation. For firms to be entrepreneurial, they must provide appropriate autonomy and incentives for individual initiative to surfice, but also promote cooperation and group ownership of an 
innovation if it is to be implemented successfully. Thus, entreprenurship often requires teams of people with unique skills and resources, expecially in cultures where collectivism is a valued historical norm.

Another important dimension of international entrepreneurship is the level of investment outside of the home country made by young ventures. In fact, with increasing globalization, a greater number of new ventures have been born global." Research has shown that new ventures that enter international markets increase their learning of new technological and thereby enhance their performance. Because of these outcomes, the amount of international entrepreneurship has been increasing in recent years.

The probability of entering international markets increases when the firm has top executives with international experience. Furthemore, the firm has a higher likelihood of successfully competing in international markets when its executives have international experience. Because of the learning and economics of scale and scope afforded by operating in international markets, both young and established internationally diversified firms often are stronger competitors in the domestic market as well. Additionaly, internationally diversified forms are generally more innovative as research has shown.

International entrepreneurship have been an important factor in the economic dev- elopment of Asia. In fact, private companies owned by Chinese families outside of China compose the fourth largest economic power in the world. Significant learning from their international ventures occurs in these busuness, and this learning enhances their success with future ventures. The learning that occurs contributes to a firm's knowledge of operating in international markets. It also contributes knowledge that can enhance a firm's new product develeopment, on which we focus in the next section.

\section{Creating Value from Innovation}

The model in Figure 1.1. shows how the firm can create value the internal processes it uses to develop and commercialize new goods and services. An entrepreneurial mindset is necessray so that managers and employees will consistently try to identify entrepreneurial opportunities that the firm can pursue by developing new goods and services and new markets. Crossfunctional teams are important to promote integrated new product design ideas and commitment to their implmentation thereafter. Effective leadership and shared values promote integration and vision for innovation and commitment to it. The end result for the firm in the creation of value for the customers and shareholders through development and commercialization of new products.

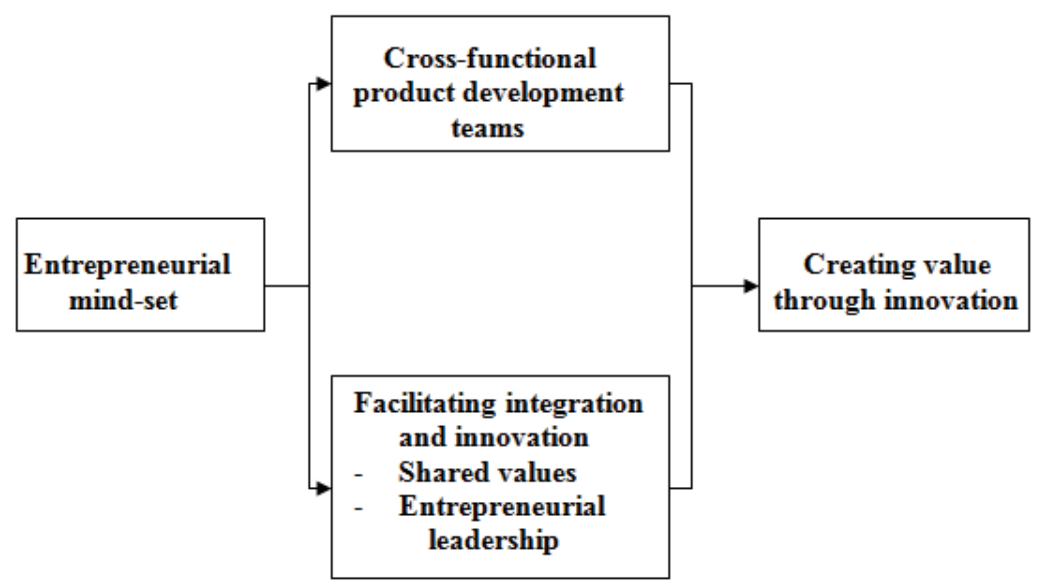

Figure 1.1. Creating Value through International Innovation Processes 


\section{Creating Value through Strategic Entreprenurship}

Newer entrepreneurial firms often are more effective than larger firms in identifying opportunities. Some believe that these firms tend to be more innovative as well because of their flexibility and willingness to take risks. Alternatively, larger and wellestablished firms often have more resources and capabilities to exploit opportunities that are identified. So, younger, entrepreneurial firms are generally opportunity seeking and more established firms are advantage seeking. However, to compete effectively in the landscape of the $21^{\text {st }}$ century, firms must identify and exploit opportunities but do so while achieving and sustaining a competitive advantage. Thus, never experimental firms must learn how to going a competitive advantage, and older more established firms must relain how to identify entrepreneurial opportunities. The concept of strategic entrepreneurship suggests that firms can be simultaneously entrepreneurial and strategy regardless of their size and age.

To be entreprenurial, firms must develop an entrepreneurial mind-set among their managers and employees. Managers must emphasize the development of their resources particularly human capital and social capital. The importnace of knowledge to identify and exploit opportunities as well as to gain and sustain a competitive advantage suggests that firms must have strong human capital. Social capital is critical for access to complementary resources from partners in order to compete effectively in domestic and international markets.

There remain many entrepreneurial opportunities in international markets. Thus, firms should seek to enter compete in international markets. Firms can learn new technologies and management practices from internatioanl markets and diffuse this knowledge throughtout the firm. Furthermore, the knowledge firms gain can contribute to their innovations. Research has shown that firms operating in international markets tend to be mo- re innovative. Small and large firms are now regularly moving into internatinal markets. Both types of firms must also be innovative to compete effectively. Thus, developing resources (human and social capital), taking advantage of opportunities in domestic and international markets, and using the resources and knowledge gained in these markets to be innovative, firms achieve competitive advantages. In so doing, they create value for their customers and shareholders.

Firms that practice strategic entrepreneurship contribute to a country 's economic development. In fact, some countries such as Ireland have made dramatic economic progress by changing the institutional rules for business operating in the country. This could be construed as a form of institutional entrepreneurship. Likewise, firms that seek to establish their technology as a standard, also representing institutional entrepreneurship, are engaging in strategic entrepreneurship because creating a standard produces a sustanable competitive advantage for the firm.

Research shows that because of its economic importance and individual motives, enterpreneurial activity is increasing across the globe. Furhermore, more woman are becoming entrepreneurs because of the economic opportunity entrepreneurship provides and the individual independence it affords. In future years, entreprenurial activity may increase the wealth of less affluent countries. Regardless, the companies that practice strategic entrepreneurship are likely to be the winners in the $21^{\text {st }}$ century.

\section{Busines and industry profile}

To acquaint lenders and investors with the nature of the business, the owner should describe it in the buseness plan. This section should begin with a statesmen of the company's general business goals and a narrower definition of its immediate objectives. Together they should spell out what the business plans to accomplish, how, when, and who will do it. Goals are broad, long-range statesments of what a company plans to do in the distant future that guide its overall direction and express its raison d'etre. In order words, they answer the question."Why am I in busieness?" Answering such a basic question appears to be obvious, but, in fact, many entrepreneurs cannot define the basic of their businesses. 


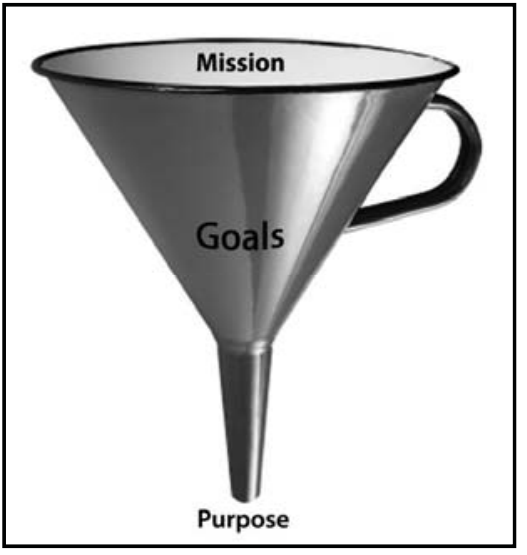

Figure 1.2. The Relationship Between Mission, Goals, and Objectives

Objectives, on the other hand, are short-term, specific performance targets thaat are attainable, measurable, and controllable. Every objective should reflect some general buseness goal and include a technique for measuring progress toward its accomplishment. To be meaningful, an objective must have a time frame for achievement. Both goals and objectives should relate to the company's basic mission (see Figure 1.2.).

When summarizing the small company's background, an owner should describe the present state of the art in industry and what she will need to succeed in the market segment in which her business will compete. The owner should then identify the current applications of the product or service in the market and include projections for future applications.

This section should provide the reader with an overview of the industry or market segment in which the new venture will operate. Industry data such as market size, growth trends, and relative economic and competitive strenghts of the major firms in the servi-industry all set the stage for a better understanding of the viability of the new product or service. Strategic issues such as ease of market entry and exit, the ability to achieve economies of scale or scope, and the existence of cyclical or seasonal economic trends further help the reader evaluate the new venture. This part of the plan also should describe significant and industry trends and an overall outlook for its future. The U.S. Industrial Outlook Handbook is an excellent reference that profiles a variety of industries and offers projections for future trends in them. Information about the evolution of the industry helps the reader comprehend its competitive dynamics.

The industry analysis should also focus on the existing an anticipated profitability of the firms in the targeted market segment. Any significant entry or exit of firms or consolidations and merger should be disussed in terms of their impact on the competitive behaviour of the market. The entrepreneur also should mention any events that have significantly altered the industry in the past years.

\section{Comparing Actual Rasults with Standards}

In the stage of the feedback loop, the idea is to look for deviation in either direction from the performance standards the company has set for itself. In other words, opportunities to improve performance arise when there is a gap between "what should be" and "what is".(see Figure 1.3) 


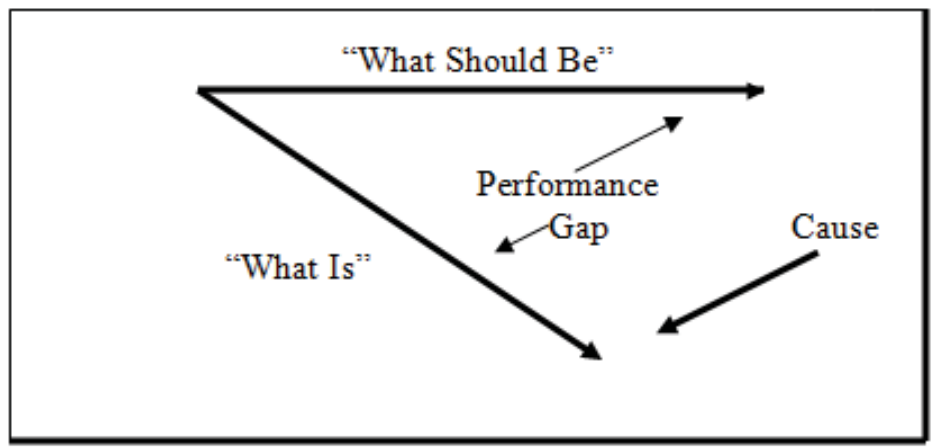

Figure 1.3. Comparing Actual Results with Performance Standards

The most serious deviations usually are those where actual performance falls far below the standard. Managers and employees must focus their efforts on figuring out why actual performance is substandard. The goal is not to hunt down the guilty part (or parties) for punishment, but to discover the cause of the subpar performance and fix it! Managers should not ignore deviations in the other direction, however. When actual performance consistently exceeds the compay's standards, it is an indication that the standards are set too low. The company should look closely at "raising the bar another notch) to spur motivation.

\section{Summary}

Strategic entrepreneurship is taking entrepreneurial actions using a strategic perspective. More specifically, it involves engaging in simultaneous opportunity seeking and competitive advantage behaviors to design implement entreprenurial strateggies to create walth.

The concept of entreprenurial opportunity, innovation, and capabilities are important to firms. Entrepreneurial opportunities represent conditions in which new products of services can satisfy a need in the market. The essence of entreprenurship to identify and exploit these opportunities. Innovation is the process of commercializing the products or processes that surfaced trough invention. Entrepreneurial capabilities include building an entrepreneurial culture, having a passion for the business and having a desire for measured risk.

Increasingly, entrepreneurship is being practiced in many countries. As used by entreprenurs, entrepreneurship and corporate entrepreneurship are strongly related to nation's economic growth. This relationship as a primary reason for the increasing use of entrepreneurship and corporate entreprenurship in countries throughout the global economy.

To create incremental and radical innovation requires effective processes. Increasingly, crossfunctional integration is vital to a firm's efforts to develop and implement internal corporate venturing activities and to comercialize the resulting innovation. Additionaly, integration and innovation can be facilitated by the development of shared values and the practice of entrepreneurial leadership.

The practice of strategic entreprenurship by all types of firms, large and small, new and more established, creates value for all stakeholders, especially for shareholders and customers. Strategic entrepreneurship also contributes to the economic development of entire nations. Thus, entrepreneurial activity is increasing throughout the world.

\section{References}

S.M. Camp, L.W. Cox kotalik, 2001. The Hallmarks of Entrepreneurial Excellence: 2001 Survey of innovative Practices, Kaufman Center for Entreprenurial Leadreship, Ewing marion Kauftman Foundati on. 
M.A. Hitt, R.D.Ireland, S.M. Camp\&D.L. Sextron, 2002. Strategic entrepreneurship integrating entreprenurial and strategic management perspectives, In M.A. Hitt, R.D. Ireland, S.M. Camp.7 D.L. Sexton (eds). Strategic Entrepreneurship Creating a New Minset. Pcford, U.K. Blacwell Publ;ishers, 1-Hitt, R.D.Ireland, S.M. Camp. \& D.L. Sexton, 2001. Strategic entrepreneurship. Entrepreneurial - strategies for weealth creating. Strategic management Journal, 22 Spewcial Issues 479-491., R.D. Irel and M.A Hitt, S.M. Camp\&D.L. Sexton, 2001. Integrating entrepreneurship and strategic managem ent action to create firm wealth, Academy of Management Executive 15(1): 49-63.

R.D. Ireland\&M.A.Hitt, 1999, Achieving and maintaining strategic cometitiveness in the 21st century. The role of strategic leadership., Academy of Management Execurive, 13(1)43-57.

G. Hamel 2000. Leading The Revolution, Boston, mA Harvard Business School Press.

T.W. Man, T.Lau\&K.F. Chan, 2002. The competitiveness of small and medium enterprises: A conteptu alization with focus on entrepreneurial competences, Journal of Business Venturing, 17: 123-142.

S, Shane\& Veenkataraman, 2000. The promise of entrepreneurship as a field of research, Academy of Management Review, 25. 217-226.

R.G. McGrath \& I.MacMillan, 2000, The Entrepreneurial Minset, Boston, MA: Harvard Business School Press.

G.Gori, 2001. An American directs Mexico City's cinema revival, The New York Times, http//www. nytimes.com, July 15. P.F. Drucker, 1998. The discipline of innovation, Harvard Business Reviw 76(6);149-157.

Schumpeter, The Theory of Economic Development.

S.D. Sarasvatty, 2000. Seminar on research perspectives in entrepreneurship (1997), Journal of Business Venturing 15. 253-273.

Branislav Djordjevic, Entrepreneurship, Nis, 2011, 64 p.

2001. Some like it hot. Entrepreneur com. October 30.

Branislav Djordjevic, Entrepreneurship, Nis, 2011, 239 p.

R.G.McGrath, 200l. Expioratory learning, innovative capacity and managerial oversight, Academy of Management Journal, 44. 118-131.

M. Kvak, 2002. What's the best commercialization strategy for startups? MIT Sloan Management Re view, 43(3); 10.

Hitt, Ireland. Camp.\&Sexton, Strategic entrepreneurship, S.W. Fowler, A.W.King, S.J. March \& B. Victor, 2000.. Beyond products: New strategic imperatives for developing competence in dynamic environments, Journal of Engineering and Rewchnology Management, 17, 357-377.

Amit, Lucier.Hitt\&Nixon, Strategies for the entreprenurial millenium.

Hitt, Ireland, Camp.\& Sexton, Strategies entreprenurship.

Hitt, Bierman, Shimizu\&Kochhar, Direct and moderating effects of human capital.

Reynolds, Camp. Bygrave, Autio \& Hay, Global Entrepreneurship Monitor.

Hitt, Ireland, Camp.\& Sexton, Strategies entrepreneurship, Amit, Lucier, Hitt\&Nixon, Strategies for the entrepreneurial millenium.

Prof. dr B. Djordjevic, Psihologija menadzmenta, FIM-Krusevac, 2008. godina.

Thomas W. Zimmerer and Norman M. Scarborough, Essentials of Entrepreneurship and Small Bus iness Management", Sec. ed., 1998, pp. 284-285. 